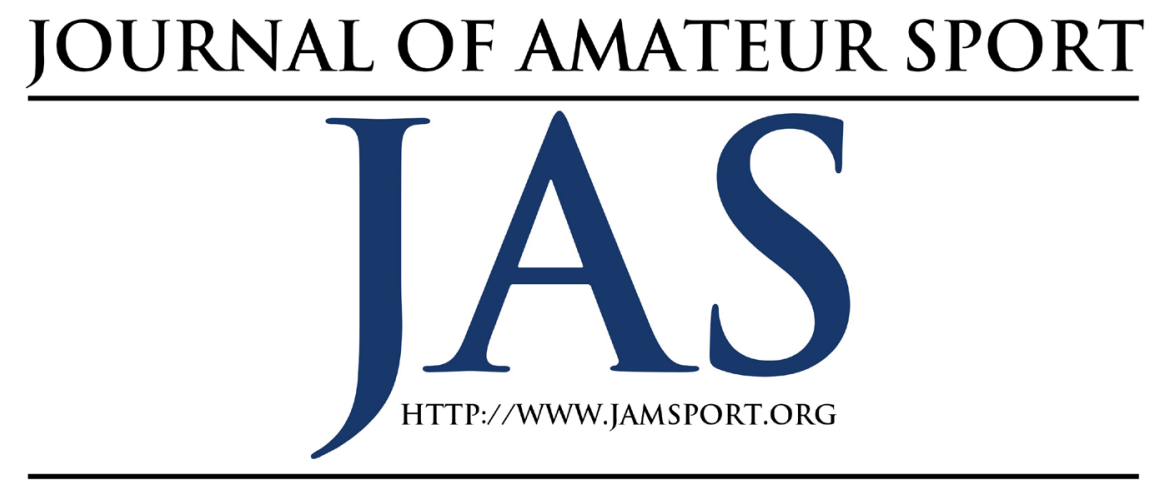

\title{
Examining the Nature and Extent of Hazing at Five NCAA Division III Institutions and Considering the Implications for Prevention
}

\author{
David Kerschner Elizabeth Allan
}

\section{University of Maine}

Building on the scholarship of Hoover (1999) and Allan and Madden (2008, 2012), we examined the nature and extent of hazing at five NCAA Division III institutions. NCAA Division III athletics has not been a focus of scholarly inquiry on the subject of hazing, despite documented accounts of athletes experiencing hazing and the outsized impact varsity athlete hazing can have on campus climate, given the high percentage of the student body at Division III institutions that may be at risk. Across the five institutions in this study, $40.9 \%$ of athletes experienced hazing, compared to $24.8 \%$ of non-athletes. The percentage of athletes that experienced hazing at the five Division III institutions ranged from $19.6 \%$ to $56.5 \%$. Athletes experienced highrisk and abusive behaviors and were more likely than their non-athlete peers to have attitudes and perceptions supportive of hazing. These results indicate there is a need for research-informed hazing prevention strategies that can be utilized by Division III colleges and universities. Researchers can build upon these findings by continuing to examine hazing and factors predictive of hazing across institutional type within NCAA Division III.

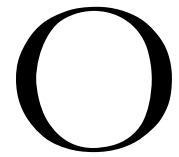

n March 19, 2016, a 19-yearold Wheaton College (Illinois) football player who had recently transferred to the college was kidnapped from his dorm room by five of his teammates (Gutowski \& St. Clair, 2017a). According to reports, the first-year athlete was punched, bound with duct tape, par- tially stripped, and had his head covered with a pillowcase before being forced into a car. In the car, the kidnappers allegedly played Middle Eastern music and suggested Muslims wanted to assault the first-year athlete. The veteran athletes drove him to an unfamiliar off-campus baseball field, threw dirt on him, took his 
cell phone and wallet, and left him stranded and underdressed in 45-degree weather (Gutowski \& St Clair, 2017b; Stack \& Hauser, 2017). Prior to midnight, the athlete reportedly made it to the emergency room and learned he had experienced muscle tears in both shoulders requiring surgery. Later withdrawing from Wheaton College, the first-year athlete was quoted as saying the hazing incident "had a devastating effect on my life. What was done to me should never occur in connection with a football program or any other activity" (Gutowski \& St. Clair, 2017a).

In September 2017, the five athletes who kidnapped the first-year athlete were charged with aggravated battery, mob action, and unlawful restraint (Stack \& Hauser, 2017). Wheaton College, a member of Division III of the National Collegiate Athletic Association (NCAA), suspended the five athletes from the fourth ranked football team and released a statement referring to hazing as unacceptable and counter to the institution's values (Gutowski \& St. Clair, 2017b; Stack \& Hauser, 2017; Wheaton College, 2017). It is alleged, however, the institutional community knew about hazing and downplayed its severity prior to the lawsuit being filed. According to the firstyear athlete's lawyer, hazing was "an open secret at Wheaton College, a practice well-established and long-standing within the Wheaton College football program, handed down from class to class while the head coach and other adults, aware of the practice, looked the other way" (Gutowski \& St. Clair, 2018). In the aftermath of the suspensions and charges, some parents of Wheaton football athletes came forward and said they had previously heard about hazing associated with the program (Koop, 2017). Charged with felonies, each of the hazers eventually accepted plea deals, were convicted of misdemeanors, and completed community service. Wheaton College reached a confidential settlement with the first-year athlete (Ward, 2018, 2019).

This example of hazing at Wheaton College illustrates some of the effects college athlete hazing can have on individuals, teams, and postsecondary institutions. With more than 190,000 athletes participating in college athletics at the NCAA Division III level (NCAA, 2019), and varsity athletes more likely to experience hazing than their non-athlete peers (e.g., Allan \& Madden, 2008; Campo, Poulos, \& Sipple, 2005), it is not surprising there have been recent public accounts of hazing at NCAA Division III institutions (e.g., Brogan, 2013; Dymski, 2012; Markham, 2016). Bowdoin College administrators, for example, reworked the institutional hazing policy in 2008 after discovering "mild and moderate hazing" occurred within the women's squash and sailing programs. Later, the college vacated a 2010-2011 men's hockey conference championship and cancelled the second half of the 2013 men's tennis season due to hazing allegations involving alcohol (Brogan, 2013; Herz, 2008). SUNY Geneseo cancelled their 2012 women's volleyball season after a report surfaced that returning players brought first-year athletes to an off-campus apartment, blindfolded and handcuffed them, and ordered them 
to drink alcoholic beverages (Dymski, 2012). Middlebury College, the University of Mary Washington, and Ursinus College each cancelled swimming seasons or suspended swimmers for participating in hazing involving alcohol consumption and the Connecticut College student newspaper documented alcohol related hazing across several varsity athletics teams (Dorning, 2011; Keith, 2019; Markham, 2016; Mayer, 2006; Schwartzburg, 2010). Beyond hazing involving alcohol consumption, Salve Regina University investigated allegations of sexually inappropriate hazing in its football program. Furthermore, six members of the Claremont-Mudd-Scripps men's track team, some of whom were naked, were reported for stealing a photo of a runner from rival Pomona College, assaulting a student employee in the process (Borg, 2018; Hutchinson, 2018; Snowdon \& Rod, 2018).

\section{Problem Statement}

Although these examples of hazing illustrate Division III athletes are at risk for experiencing potentially humiliating, degrading, or dangerous hazing activities, there is a dearth of scholarship focused on NCAA Division III athlete hazing experiences. Empirical research focused on hazing in NCAA college athletics has not often specified the divisional level of participants, instead hazing is typically analyzed from a cross-divisional perspective (e.g., Allan \& Madden, 2008; Van Raalte, Cornelius, Linder, \& Brewer, 2007). Other researchers examining hazing in postsecondary athletics have focused on university athletes in Canada (e.g., Bryshun \& Young, 1999; Johnson, Guerrero, Holman, Chin, \& Signer-Kroeker, 2018) or the United Kingdom (e.g., Anderson, McCormack, \& Lee, 2012; Lafferty, Wakefield, \& Brown, 2016).

Hoover (1999) concluded that NCAA Division III athletes experienced similar rates of hazing as their Division I and Division II peers, but the division has changed substantially in the two decades since these findings were published. Division III - the largest division of the NCAA, constituting approximately $40 \%$ of the association's overall membership-has experienced tremendous growth since 1990, expanding from 300 members to 449 members as many former National Association of Intercollegiate Athletics (NAIA) colleges and universities opted to join the NCAA (Lederman, 2008; NCAA, 2019; Powers, 2008). Much of this growth was realized between 1990 and 2008, with NCAA Division III membership increasing roughly seven institutions per year during this time. This expansion led to greater institutional and philosophical diversity within NCAA Division III, with newer members tending to support sponsoring fewer sports, lower overall student body sport participation rates, and increased levels of competitiveness (Lederman, 2008; Powers, 2008). Beaver (2014) documented the shifting landscape of Division III during this time and reported the addition of less selective, athlete enrollment-driven institutions. Miranda (2009) noted the variety of academic profiles and athletic philosophies of the 
institutions comprising NCAA Division III after this growth, commented on the relative lack of empirical research focused on the division, and asserted that future research should focus on examining institutional differences and athlete outcomes within the division.

Given this membership growth, greater emphasis on competitiveness, and increase in institutional diversity in the two decades since Hoover's (1999) findings, research focused on hazing in the context of NCAA Division III athletics examining athlete experiences within the division, rather than comparing their experiences to their Division I and Division II peers, is warranted. We aimed to begin filling this gap by examining hazing experiences of athletes at five NCAA Division III institutions and sought to answer the following research questions: (a) What is the nature and extent of Division III athlete hazing experiences at these institutions? (b) Do athlete hazing experiences differ across these Division III campuses? (c) Do athletes at these Division III institutions have different hazing experiences than their non-athlete peers?

\section{Relevant Literature}

Hazing, defined by Hoover (1999) as "any activity expected of someone joining a group that humiliates, degrades, abuses or endangers, regardless of the person's willingness to participate" ( $p$. $8)^{1}$, is a form of interpersonal violence

1 This definition has expanded since Hoover (1999) to include activities expected of someone joining or maintaining membership in a group. See Allan and Madden (2008, 2012). that can interfere with the goals of postsecondary education and impede the benefits of participating in college athletics by threatening the health and safety of college athletes (Langford, 2004; Srabstein, 2008; Srabstein et al., 2008). Emotional, psychological, and physical harm are documented outcomes of hazing and, at times, the consequences of hazing can be lethal (Allan \& Madden, 2008; Nuwer, 2018). Survey-based inquiries (e.g., Allan \& Madden, 2008; Hamilton, Scott, O’Sullivan, \& LaChappelle, 2013; Hoover, 1999; Johnson et al., 2018; Waldron, 2015) in the United States and Canada have found: (a) college athletes experience hazing at high rates and/or rates higher than their non-athlete peers, with between $58 \%$ and $79 \%$ of athletes indicating they participated in behaviors meeting the definition of hazing; (b) college athletes participate in high-risk and abusive hazing behaviors (e.g., participation in a drinking game, drinking large amounts of alcohol, verbal abuse from other members, acting as a servant to other members, sleep deprivation, wearing embarrassing clothing); (c) hazing occurs across a range of collegiate athletic teams; (d) athletes perceive their coaches to have awareness of hazing and, at times, report that their coaches are present for the hazing activities; and (e) a gap exists between college athlete experiences of hazing and their ability to recognize and label those experiences as hazing (e.g., Hoover, 1999; Allan \& Madden, 2008).

Hazing and gender is one area where scholars that have utilized quantitative 
methods have not produced consistent results. Hoover (1999) and Allan \& Madden (2008) found that male college athletes were more likely to experience hazing than female athletes. Hamilton et al. (2013) and McGlone (2010), however, found there was no difference related to hazing and gender and Waldron (2015) concluded that gender was not a statistically significant predictor of athlete participation in mild or severe hazing behaviors. Furthermore, Johnson et al. (2018) found that female college athletes were more likely to experience hazing. Hamilton and colleagues hypothesized that evolving attitudes related to gender, sexuality, and sport might be the cause for these divergent results. While gender norms, attitudes toward sexual identity, and the role of sport in society provide part of the rationale for college athlete hazing and explain the hazing behaviors athletes experience, researchers that have examined hazing in the context of college athletics have also concluded that hazing persists due to: (a) an incorrect belief that hazing is an effective method of developing team cohesion, (b) athlete inability to recognize hazing and unwillingness to report hazing, and (c) coaches and athletic administrators acting as barriers to hazing prevention (Campo et al., 2005; Caperchione \& Holman, 2004; Kowalski \& Waldron, 2010; McGlone, 2010; Van Raalte et al., 2007; Waldron \& Kowalski, 2009).

\section{Conceptual Framing}

Our research sought to explore athlete hazing through the lenses of campus ecology and campus climate. Campus climate refers to the "overall ethos or atmosphere of a college campus mediated by the extent to which individuals feel a sense of safety, belonging, engagement within the environment, and value as members of the community" (Renn \& Patton, 2011, p. 248). Throughout this investigation, the concept of campus climate framed the design of data gathering and analysis related to current attitudes and perceptions about the institutional and organizational environment and perceptions of hazing at a particular campus. Given the diversity of Division III institutions, this inquiry was also designed to account for institutional context including institutional type, student demographics, and geographic location. Campus ecology, as adapted from a public health framework, informed our approach to the study design, analysis, and interpretation of data by exploring factors that may influence hazing at multiple levels of the campus environment including intrapersonal, interpersonal, group/organization, university, community, and societal (Dahlburg \& Krug, 2002).

\section{Methods}

Bass and colleagues (2014) suggested that four types of Division III institutions exist: academically elite institutions, large public universities, mission-driven privates, and liberal arts colleges and universities (Katz, Pfleegor, Schaeperkoetter, \& Bass, 2015). Accordingly, the five institutions from which data were collected for this investigation included a 
mission-driven private college located in the Midwest, a liberal arts college located in the West, a large public university in the Northeast, and two academically elite institutions in the Northeast. These institutions were selected from a larger group of colleges and universities that expressed an interest in assessing the nature and extent of hazing on their campuses between April 2013 and May 2018. Waldron (2016) commented on the importance of administrative approval for conducting hazing research in the context of athletics (i.e., administrators may not be willing to provide approval for participant recruitment because a) the research might reveal a major hazing issue or b) administrators might hold a belief that hazing is not an issue at their institution). Participating institutions were selected for inclusion in this study if they had NCAA Division III athletics programs. Undergraduate enrollment at each of the selected institutions ranged from approximately 1,500 to 5,500. Table 1 provides an overview of each of the institutions.

\section{Sample}

Each institution provided researchers with a random sample of student email addresses, representing at least $25 \%$ of their full-time undergraduate student population between the ages of 18-25. Participating colleges and universities provided samples that represented between $46.6 \%$ and $100 \%$ of their undergraduate student population, $67.7 \%$ overall across all five institutions. Surveys were administered for the five campuses and remained open for either a two or three-week period, depending on institutional needs. Campus response rates ranged from $13.0 \%$ to $43.6 \%, 26.5 \%$ overall, and exceeded response rates from previous examinations of hazing in a postsecondary context. Completion rates ranged from $68.2 \%$ to $84.3 \%$, $72.1 \%$ overall, and are comparable to rates observed in previous studies (Allan \& Madden, 2008; Allan, Kerschner, \& Payne, 2019).

In aggregate, 2,999 students participated across the five Division III campuses. These participants were asked

Table 1

Institutional Overview

\begin{tabular}{lcccc}
\hline NCAA Division III Campus & Location & $\begin{array}{c}\text { Undergrad } \\
\text { Enrollment }\end{array}$ & $\begin{array}{c}\text { Overall } \\
\text { Athlete } \\
\text { Percentage }\end{array}$ & $\begin{array}{c}\text { Sample } \\
\text { Athlete } \\
\text { Percentage }\end{array}$ \\
\hline Academically Elite Institution A & Northeast & 1,900 & $34.2 \%$ & $33.9 \%$ \\
Private Liberal Arts College & West & 1,500 & $26.5 \%$ & $25.0 \%$ \\
Academically Elite Institution B & Northeast & 5,500 & $17.7 \%$ & $15.2 \%$ \\
Mission-Driven Private College & Midwest & 2,300 & $20.7 \%$ & $31.5 \%$ \\
Large Public University & Northeast & 5,500 & $9.9 \%$ & $9.8 \%$ \\
\hline
\end{tabular}


which type of organization, group, or team they had been most involved with during their time on campus (e.g., varsity athletic team, fraternity or sorority, performing arts organization, academic club), referred to as their "primary organization" throughout the remainder of the survey. Some respondents indicated they had not belonged to any groups, organizations, or teams while on campus. Of the 2,505 respondents who identified a primary organization, 590 (23.6\%) indicated their primary organization was a varsity athletic team and 1,915 (76.4\%) indicated their primary organization was a group other than a varsity athletic team. Participants who selected varsity athletic team as their primary organization were not asked to specify the sports in which they participated in order to avoid potentially collecting personally identifiable information, shorten the length of the survey, and ensure a viable survey response rate compared to other student groups. Due to institutional constraints, demographic data regarding race/ethnicity and gender identity were not collected for the Mission-Driven Private College, but across the four institutions where demographic information were collected, $41.7 \%$ of varsity athletes identified as men, $58.3 \%$ identified as women, and $0.0 \%$ identified as transgender. For non-varsity athletes, $30.8 \%$ identified as men, $68.4 \%$ identified as women, and $0.8 \%$ identified as transgender. Nearly 80 percent $(78.9 \%)$ of varsity athletes identified as white and $21.1 \%$ of varsity athletes identified with a minoritized student population, whereas $70.1 \%$ of non-athletes indicated they were white and $29.9 \%$ belonged to minoritized student populations. Table 2 provides a summary of athlete and non-athlete respondent demographics.

The demographics of participants and characteristics of the site sample share commonalities with the overall demographics and composition of NCAA Division III. Site selection yielded five institutions that, when considered in the typology outlined by Bass et al. (2014), cover all the institutional types and much of the institutional diversity within the division. As with the entirety of NCAA Division III, participating institutions had a range of enrollments, scope, and missions and there is geographic diversity with institutions located in the Northeast, Midwest, and West. Furthermore, four of the five participating institutions are private, a percentage in line with the overall NCAA Division III figure of $80 \%$. The athlete sample percentage

Table 2

Participant Demographic Overview

\begin{tabular}{lccccc}
\hline $\begin{array}{l}\text { Demographic } \\
\text { Item }\end{array}$ & $\begin{array}{c}\text { Male } \\
\text { Percentage }\end{array}$ & $\begin{array}{c}\text { Female } \\
\text { Percentage }\end{array}$ & $\begin{array}{c}\text { Transgender } \\
\text { Percentage }\end{array}$ & $\begin{array}{c}\text { White } \\
\text { Percentage }\end{array}$ & $\begin{array}{c}\text { Minoritized } \\
\text { Percentage }\end{array}$ \\
\hline Varsity Athletes & $41.7 \%$ & $58.3 \%$ & $0.0 \%$ & $78.9 \%$ & $21.1 \%$ \\
Non-Athletes & $30.8 \%$ & $68.4 \%$ & $0.8 \%$ & $70.1 \%$ & $29.9 \%$ \\
\hline
\end{tabular}


$(23.6 \%)$ at these Division III campuses closely mirrors the overall athlete percentage throughout NCAA Division III $(25.0 \%)$, as does the percentage of white and minoritized students attending these institutions ("Division III 2018-2019 facts and figures," 2018). One weakness of the sample, however, is the relatively low percentage of male athlete responses. Although male athletes comprise a higher percentage of athlete participants than the percentage of male non-athlete participants, this percentage $(41.7 \%)$ is much lower than the percentage of male athletes throughout NCAA Division III $(58.3 \%)$. Other researchers using survey-based inquiries to examine hazing in college athletics such as Waldron (2015) and Johnson et al. (2018) have had similar disproportionality. Table 3 provides an overview of sample athlete demographics compared to overall NCAA Division III demographics.

\section{Instrument}

A modified version of the National Survey of Student Hazing (Allan \& Madden, 2008), amended to include questions examining students' attitudes and beliefs about hazing, was used to Table 3

Demographic Overview

\begin{tabular}{lcc}
\hline Demographic Item & $\begin{array}{c}\text { NCAA Division III } \\
\text { Percentage }\end{array}$ & $\begin{array}{c}\text { Athlete Sample } \\
\text { Percentage }\end{array}$ \\
\hline Male Athletes & $58.3 \%$ & $41.7 \%$ \\
Female Athletes & $41.7 \%$ & $58.3 \%$ \\
White Athletes & $76.4 \%$ & $78.9 \%$ \\
Minoritized Athletes & $23.6 \%$ & $21.1 \%$ \\
Overall Athlete Percentage & $25.0 \%$ & $23.6 \%$ \\
\hline
\end{tabular}

gather data for this investigation. After providing demographic information and selecting a primary organization, respondents were then given a list of behaviors which met Hoover's (1999) definition of hazing and were asked if the behaviors happened to them as part of joining their varsity athletic team or participating in their non-varsity athletic team groups, organizations, and clubs. In total, the modified survey incorporated more than 100 data points related to student experiences with behaviors meeting the definition of hazing, student experiences with hazing prevention strategies, perceptions of hazing on campus, experiences with hazing prior to college, and attitudes and beliefs about hazing. Replicating methods used in previous studies of hazing (e.g., Allan \& Madden, 2012; Allan et al., 2019; Hoover, 1999), the term "hazing" was not used in the survey invitation or until after students responded to which behaviors they had experienced as members of their groups, teams, and organizations in the survey.

\section{Analysis}

In response to the research questions guiding the investigation, data from 2,999 
students across the five NCAA Division III campuses that completed the survey were first analyzed using the Statistical Package for the Social Sciences (SPSS) to aggregate databases generated by each institutional survey and to conduct basic descriptive statistics. Chi-square tests for independence were utilized to examine the relationship between categorical independent variables such as varsity athlete status, gender, and race and categorical dependent variables such as whether or not a student had experienced hazing and attitudes and perceptions of hazing. The descriptive statistics and basic inferential statistics were used to examine the nature and extent of Division III athlete hazing experiences and if athletes at the participating Division III campuses had different hazing experiences than their non-athlete peers, informing the findings subsequently presented.

\section{Findings}

Of the 2,505 students who indicated a primary organization at their NCAA Division III institution, 2,168 (86.5\%) responded to the questions about specific behaviors they may have encountered to join or maintain membership in that primary team or organization. Of these respondents, $28.8 \%$ indicated they experienced at least one behavior meeting the definition of hazing. Chisquare analysis revealed a significant relationship between varsity athlete status and students experiencing behaviors meeting the definition of hazing, X2 (1, $n=2,168)=50.779, p<0.001$. As noted in Table $4,40.9 \%$ of varsity athletes experienced behaviors meeting the definition of hazing and $24.8 \%$ of non-varsity athletes (i.e., individuals belonging to primary organizations other than varsity athletic teams) experienced hazing. Varsity athletes (93.4\%) were also statistically more likely than their non-varsity athlete peers $(87.1 \%)$ to participate in non-hazing team-building / prevention activities such as participating in group outings led by trained professionals, attending alcohol-free functions, doing volunteer community service, and participating in facilitated ropes courses (X2 (1, $n=2,178)=69.164, p<0.001)$.

Varsity athletes and non-varsity athletes experienced many of the same hazing behaviors most frequently, as noted in Table 5. The hazing behaviors varsity athletes most frequently experienced were participating in a drinking game $(21.8 \%)$, attending a skit night or roast where other members were humiliated $(13.2 \%)$, associating with specific people and not others $(11.2 \%)$, singing or chanting in a public situation that is

Table 4

Hazing and NCAA Division III Varsity Athlete Status

\begin{tabular}{lccc}
\hline Varsity Athlete Status & $\mathrm{N}$ & $\begin{array}{c}\text { Number } \\
\text { Experiencing Hazing }\end{array}$ & $\begin{array}{c}\text { Percentage } \\
\text { Experiencing Hazing }\end{array}$ \\
\hline Varsity Athletes & 541 & 221 & $40.9 \%$ \\
Non-Varsity Athletes & 1,627 & 404 & $24.8 \%$ \\
\hline
\end{tabular}


not a related event $(10.4 \%)$, and wearing embarrassing clothing $(8.9 \%)$. There was a statistically significant relationship between varsity athlete status and experiencing hazing across 13 of the 35 hazing behaviors (37.1\%) included in the survey. In order to join or maintain membership in their group, team, or organization, varsity athletes were statistically more likely than their non-varsity athlete peers to participate in the following activities:

- Attend a skit night or roast where other members were humiliated.

- Wear clothing that is embarrassing and not a part of a uniform.

- Get a tattoo or pierce a body part.

- Shave their head or other body parts.

- Associate with specific people and not others.
- Act as a personal servant to other members.

- Be nude or partially nude in front of a group or in a public place.

- Participate in a "kangaroo court" or mock trial.

- Be tied up, taped, or confined to a small space.

- Be dropped off in an unfamiliar location.

- Drink large amounts of a non-alcoholic beverage.

- Participate in a drinking game.

- Keep a tally of men or women with whom they had sex.

Non-varsity athletes were not statistically more likely than their NCAA Division III athlete peers to experience any hazing behaviors included in the survey.

Table 5

Most Frequently Experienced Athlete Hazing Behaviors

\begin{tabular}{lcc}
\hline Behavior & $\begin{array}{c}\text { Athlete } \\
\text { Percentage }\end{array}$ & $\begin{array}{c}\text { Non-Athlete } \\
\text { Percentage }\end{array}$ \\
\hline Participate in a drinking game & $21.8 \%$ & $9.0 \%$ \\
Attend a skit night or roast where other members & $13.2 \%$ & $3.9 \%$ \\
are humiliated & $11.2 \%$ & $7.8 \%$ \\
Associate with specific people and not others & $10.4 \%$ & $7.9 \%$ \\
Sing or chant in a public situation that is not & & $4.2 \%$ \\
a related event & $8.9 \%$ & $4.8 \%$ \\
Wear clothing that is embarrassing and not part of & $8.0 \%$ & $5.3 \%$ \\
a uniform & $6.3 \%$ & $4.2 \%$ \\
Act as a personal servant to other members & $4.8 \%$ & $1.5 \%$ \\
Be yelled, screamed, or cursed at by other members & $4.3 \%$ & $1.7 \%$ \\
Be awakened at night by other members & $4.1 \%$ & \\
Drink large amounts of a non-alcoholic beverage & & \\
Dropped off in an unfamiliar location & & \\
\hline
\end{tabular}


Table 6

Hazing Variables with a Statistically Significant Relationship with Athlete Status

\begin{tabular}{lcccc}
\hline Variables & $\mathrm{df}$ & $\mathrm{n}$ & $\begin{array}{c}\text { Chi-Square } \\
\text { Value }\end{array}$ & p-value \\
\hline $\begin{array}{l}\text { Students experienced hazing joining their primary } \\
\text { organization }\end{array}$ & 1 & 2,168 & 50.779 & $<0.001$ \\
$\begin{array}{l}\text { Students were aware of hazing activities prior to } \\
\text { joining their primary organization }\end{array}$ & 2 & 566 & 7.963 & 0.019 \\
$\begin{array}{l}\text { Alumni present during hazing } \\
\begin{array}{l}\text { Students had heard of other groups hazing on } \\
\text { campus }\end{array}\end{array}$ & 1 & 326 & 5.524 & 0.019 \\
$\begin{array}{l}\text { Students indicate they were hazed to join or } \\
\text { maintain participation in primary organization }\end{array}$ & 2 & 1,599 & 14.100 & $<0.001$ \\
\hline
\end{tabular}

Athlete Hazing Experiences and Attitudes

Additional chi-square tests indicated that there was a statistically significant relationship between varsity athlete status and several hazing variables, as illustrated in Table 6.

Varsity athletes $(22.9 \%)$ responded that they were less likely than their non-athlete peers $(34.1 \%)$ to be aware of the activities meeting the definition of hazing prior to joining their group, organization, or team. Furthermore, athletes were also statistically significantly less likely to indicate that alumni were present during hazing activities $(24.8 \%$ of athletes indicated alumni were present, $37.8 \%$ of non-athletes indicated alumni were present) and that they had heard of other groups engaging in hazing on campus $(72.1 \%$ of athletes, $81.0 \%$ of non-athletes). When asked directly, varsity athletes $(6.9 \%)$ were more likely to indicate that they were hazed when joining their teams than other student respondents $(4.0 \%)$. Finally, chi-square analyses indicated a statistically signifi- cant relationship between varsity athlete status and attitudes towards hazing and perceptions of hazing, with athletes less likely than their non-athlete peers to agree with the following statements:

- It can be hazing even if someone agrees to participate.

- Hazing is not an effective way to create bonding.

- There is no good reason to haze new members of a group.

- Hazing is a problem on this campus.

- Hazing is not an effective way to initiate new members.

- Hazing is a problem because it can cause physical harm.

- Hazing is a problem because it can cause emotional harm.

- I do not need to be hazed to feel like I belong.

- I would be more likely to report hazing if I could do it anonymously.

- I would be more likely to report hazing if I thought it would make a difference. 
Table 7

Varsity Atblete Attitudes and Beliefs about Hazing

\begin{tabular}{|c|c|c|c|c|c|c|}
\hline Statement & $\begin{array}{l}\text { Strongly } \\
\text { Agree }\end{array}$ & Agree & $\begin{array}{l}\text { Agree }> \\
\text { Disagree }\end{array}$ & $\begin{array}{l}\text { Disagree } \\
>\text { Agree }\end{array}$ & Disagree & $\begin{array}{l}\text { Strongly } \\
\text { Disagree }\end{array}$ \\
\hline $\begin{array}{l}\text { It can be hazing even } \\
\text { if someone agrees to } \\
\text { participate }\end{array}$ & $20.8 \%$ & $32.7 \%$ & $18.6 \%$ & $14.1 \%$ & $8.8 \%$ & $5.1 \%$ \\
\hline $\begin{array}{l}\text { Hazing is not an } \\
\text { effective way to create } \\
\text { bonding }\end{array}$ & $33.8 \%$ & $26.4 \%$ & $18.2 \%$ & $11.3 \%$ & $4.9 \%$ & $5.3 \%$ \\
\hline $\begin{array}{l}\text { There is no good } \\
\text { reason to haze new } \\
\text { members of a group }\end{array}$ & $39.0 \%$ & $26.7 \%$ & $18.6 \%$ & $7.2 \%$ & $4.3 \%$ & $4.1 \%$ \\
\hline $\begin{array}{l}\text { Hazing is a problem } \\
\text { on this campus }\end{array}$ & $6.2 \%$ & $8.7 \%$ & $13.7 \%$ & $27.6 \%$ & $25.9 \%$ & $17.8 \%$ \\
\hline $\begin{array}{l}\text { Hazing is not an } \\
\text { effective way to initiate } \\
\text { new members }\end{array}$ & $33.9 \%$ & $30.8 \%$ & $18.0 \%$ & $9.1 \%$ & $5.0 \%$ & $3.3 \%$ \\
\hline $\begin{array}{l}\text { Hazing is a problem } \\
\text { because it can cause } \\
\text { physical harm }\end{array}$ & $38.4 \%$ & $38.0 \%$ & $13.8 \%$ & $5.8 \%$ & $1.7 \%$ & $2.3 \%$ \\
\hline $\begin{array}{l}\text { Hazing is a problem } \\
\text { because it can cause } \\
\text { emotional harm }\end{array}$ & $45.5 \%$ & $34.5 \%$ & $12.6 \%$ & $3.7 \%$ & $1.7 \%$ & $2.1 \%$ \\
\hline $\begin{array}{l}\text { I do not need to be } \\
\text { hazed to feel like I } \\
\text { belong to a group }\end{array}$ & $58.9 \%$ & $32.4 \%$ & $5.8 \%$ & $1.2 \%$ & $0.4 \%$ & $1.2 \%$ \\
\hline $\begin{array}{l}\text { I would be more } \\
\text { likely to report hazing } \\
\text { if I could do it } \\
\text { anonymously }\end{array}$ & $24.0 \%$ & $26.9 \%$ & $20.2 \%$ & $11.6 \%$ & $8.3 \%$ & $9.1 \%$ \\
\hline $\begin{array}{l}\text { I would be more likely } \\
\text { to report hazing if I } \\
\text { thought it would make } \\
\text { a difference }\end{array}$ & $26.0 \%$ & $31.7 \%$ & $19.6 \%$ & $7.7 \%$ & $8.5 \%$ & $6.5 \%$ \\
\hline
\end{tabular}

Journal of Amateur Sport Volume Seven, Issue One Kerschner et al, 2021 106 
Table 8

Non-Varsity Athlete Attitudes and Beliefs about Hazing

\begin{tabular}{|c|c|c|c|c|c|c|}
\hline Statement & $\begin{array}{l}\text { Strongly } \\
\text { Agree }\end{array}$ & Agree & $\begin{array}{l}\text { Agree }> \\
\text { Disagree }\end{array}$ & $\begin{array}{l}\text { Disagree } \\
>\text { Agree }\end{array}$ & Disagree & $\begin{array}{l}\text { Strongly } \\
\text { Disagree }\end{array}$ \\
\hline $\begin{array}{l}\text { It can be hazing } \\
\text { even if someone } \\
\text { agrees to participate }\end{array}$ & $34.9 \%$ & $37.0 \%$ & $14.5 \%$ & $7.4 \%$ & $3.2 \%$ & $2.9 \%$ \\
\hline $\begin{array}{l}\text { Hazing is not an } \\
\text { effective way to } \\
\text { create bonding }\end{array}$ & $43.5 \%$ & $26.0 \%$ & $14.2 \%$ & $9.6 \%$ & $4.3 \%$ & $2.4 \%$ \\
\hline $\begin{array}{l}\text { There is no good } \\
\text { reason to haze new } \\
\text { members of a group }\end{array}$ & $47.2 \%$ & $29.2 \%$ & $13.4 \%$ & $5.8 \%$ & $2.7 \%$ & $1.7 \%$ \\
\hline $\begin{array}{l}\text { Hazing is a problem } \\
\text { on this campus }\end{array}$ & $10.1 \%$ & $16.3 \%$ & $24.1 \%$ & $23.0 \%$ & $15.5 \%$ & $10.9 \%$ \\
\hline $\begin{array}{l}\text { Hazing is not } \\
\text { an effective way } \\
\text { to initiate new } \\
\text { members }\end{array}$ & $43.1 \%$ & $31.0 \%$ & $14.5 \%$ & $7.0 \%$ & $3.0 \%$ & $1.4 \%$ \\
\hline $\begin{array}{l}\text { Hazing is a problem } \\
\text { because it can cause } \\
\text { physical harm }\end{array}$ & $53.7 \%$ & $33.5 \%$ & $8.3 \%$ & $2.8 \%$ & $1.3 \%$ & $0.5 \%$ \\
\hline $\begin{array}{l}\text { Hazing is a problem } \\
\text { because it can cause } \\
\text { emotional harm }\end{array}$ & $60.9 \%$ & $29.2 \%$ & $6.7 \%$ & $1.7 \%$ & $0.9 \%$ & $0.5 \%$ \\
\hline $\begin{array}{l}\text { I do not need to be } \\
\text { hazed to feel like I } \\
\text { belong to a group }\end{array}$ & $70.4 \%$ & $24.7 \%$ & $3.5 \%$ & $1.0 \%$ & $0.3 \%$ & $0.1 \%$ \\
\hline $\begin{array}{l}\text { I would be more } \\
\text { likely to report } \\
\text { hazing if I could do } \\
\text { it anonymously }\end{array}$ & $31.8 \%$ & $31.0 \%$ & $20.1 \%$ & $6.8 \%$ & $6.2 \%$ & $4.1 \%$ \\
\hline $\begin{array}{l}\text { I would be more } \\
\text { likely to report } \\
\text { hazing if I thought } \\
\text { it would make a } \\
\text { difference }\end{array}$ & $37.2 \%$ & $33.7 \%$ & $16.7 \%$ & $4.7 \%$ & $4.3 \%$ & $3.4 \%$ \\
\hline
\end{tabular}

Journal of Amateur Sport Volume Seven, Issue One Kerschner et al, 2021 107 


\section{Athlete Hazing and NCAA Division III Institutions}

Chi-square tests for independence also revealed a significant association between NCAA Division III campus and whether or not varsity athletes experienced hazing behaviors X2 (4, $n=541)=30.052, p<0.001$. Overall, $56.5 \%$ of athletes at Academically Elite Institution A, $42.4 \%$ of athletes at Private Liberal Arts College, $36.8 \%$ of athletes at Academically Elite Institution B, 35.2\% of athletes at Mission Driven Private College, and $19.6 \%$ of athletes at Large Public University experienced behaviors meeting the definition of hazing. As shown in Table 9, varsity athletes at four out of the five NCAA Division III campuses were more likely to experience hazing than their non-varsity athlete peers. Athletes at Academically Elite Institutions $\mathrm{A}$ and $\mathrm{B}(4.7 \%)$ were more likely to indicate that they had participated in hazing someone else at their college than their peers at Private Liberal Arts College (1.8\%), Mission Driven Private College $(0.5 \%)$, or Large Public University $(1.8 \%)$.

Furthermore, there was a statistically significant relationship between institutional type and attitudes towards hazing and perceptions of hazing, with varsity athletes at academically elite institutions less likely, as illustrated in Table 10, to agree with the following statements:

- Hazing is not an effective way to create bonding.

- There is no good reason to haze new members of a group.

- Hazing is a problem on this campus.

- Hazing is not an effective way to initiate new members.

- Hazing is a problem because it can cause physical harm.

- Hazing is a problem because it can cause emotional harm.

Table 9

Hazing and NCAA Division III Campuses

\begin{tabular}{|c|c|c|c|c|}
\hline NCAA Division III Campus & $\begin{array}{l}\text { Athletes } \\
\text { Experiencing } \\
\text { Hazing }\end{array}$ & $\begin{array}{c}\text { Percentage } \\
\text { of Athletes } \\
\text { Hazed }\end{array}$ & $\begin{array}{c}\text { Non-Athletes } \\
\text { Experiencing } \\
\text { Hazing }\end{array}$ & $\begin{array}{c}\text { Percentage } \\
\text { of Non- } \\
\text { Athletes } \\
\text { Hazed }\end{array}$ \\
\hline $\begin{array}{l}\text { Academically Elite } \\
\text { Institution A }\end{array}$ & $91 / 161$ & $56.5 \%$ & $85 / 286$ & $29.7 \%$ \\
\hline Private Liberal Arts College & $25 / 59$ & $42.4 \%$ & $60 / 162$ & $37.0 \%$ \\
\hline $\begin{array}{l}\text { Academically Elite } \\
\text { Institution B }\end{array}$ & $14 / 38$ & $36.8 \%$ & $56 / 224$ & $25.0 \%$ \\
\hline $\begin{array}{l}\text { Mission-Driven Private } \\
\text { College }\end{array}$ & $80 / 227$ & $35.2 \%$ & $92 / 494$ & $18.6 \%$ \\
\hline Large Public University & $11 / 56$ & $19.6 \%$ & $111 / 469$ & $23.7 \%$ \\
\hline
\end{tabular}


Table 10

Institutional Type and Varsity Atblete Attitudes and Beliefs about Hazing

\begin{tabular}{|c|c|c|c|c|}
\hline Statement & $\begin{array}{l}\text { Academically } \\
\text { Elite } \\
\text { Institutions } \\
\% \text { Agree }\end{array}$ & $\begin{array}{l}\text { Private } \\
\text { Liberal } \\
\text { Arts College } \\
\% \text { Agree }\end{array}$ & $\begin{array}{l}\text { Mission } \\
\text { Driven } \\
\text { Private } \\
\% \text { Agree }\end{array}$ & $\begin{array}{l}\text { Large } \\
\text { Public } \\
\text { University } \\
\% \text { Agree }\end{array}$ \\
\hline $\begin{array}{l}\text { Hazing is not an effective way to } \\
\text { create bonding }\end{array}$ & $44.1 \%$ & $64.3 \%$ & $70.4 \%$ & $71.2 \%$ \\
\hline $\begin{array}{l}\text { There is no good reason to haze } \\
\text { new members of a group }\end{array}$ & $53.1 \%$ & $67.3 \%$ & $72.8 \%$ & $80.0 \%$ \\
\hline $\begin{array}{l}\text { Hazing is a problem on this } \\
\text { campus }\end{array}$ & $8.0 \%$ & $14.3 \%$ & $20.3 \%$ & $18.4 \%$ \\
\hline $\begin{array}{l}\text { Hazing is not an effective way to } \\
\text { initiate new members }\end{array}$ & $54.0 \%$ & $64.3 \%$ & $70.4 \%$ & $79.6 \%$ \\
\hline $\begin{array}{l}\text { Hazing is a problem because it } \\
\text { can cause physical harm }\end{array}$ & $73.9 \%$ & $76.8 \%$ & $76.2 \%$ & $86.0 \%$ \\
\hline $\begin{array}{l}\text { Hazing is a problem because it } \\
\text { can cause emotional harm }\end{array}$ & $76.7 \%$ & $78.6 \%$ & $80.7 \%$ & $90.0 \%$ \\
\hline $\begin{array}{l}\text { I would be more likely to report } \\
\text { hazing if I thought it would } \\
\text { make a difference }\end{array}$ & $48.0 \%$ & $66.1 \%$ & $60.0 \%$ & $73.5 \%$ \\
\hline
\end{tabular}

- I would be more likely to report hazing if I thought it would make a difference.

\section{Athlete Hazing, Gender, and Race}

Data on participant race and gender were collected at four of the five institutions participating in this study. We were unable to collect demographic information at the Mission Driven Private College where $35.2 \%$ of athletes overall experienced hazing behaviors. Across the four campuses where demographic information was collected, a slightly higher percentage of male varsity athletes (47.4\%) experienced hazing behaviors than female varsity athletes (43.1\%), as illustrated in Table 11.

Chi-square analyses, however, revealed that this difference is not statistically significant X2 $(1, n=314)=0.566$, $p=0.452$ and that there were not statistically significant associations between gender and athlete experiences with hazing or between gender and athlete attitudes and perceptions of hazing. Furthermore, chi-square tests for independence also indicated that there were no statistically significant relationships between race and athlete hazing experiences, attitudes towards hazing, and perceptions of hazing. 
Table 11

Varsity Athlete Hazing and Gender

\begin{tabular}{lccc}
\hline Gender & $\mathrm{N}$ & $\begin{array}{c}\text { Number } \\
\text { Experiencing } \\
\text { Hazing }\end{array}$ & Percentage Experiencing Hazing \\
\hline Male Athletes & 133 & 63 & $47.4 \%$ \\
Female Athletes & 181 & 78 & $43.1 \%$ \\
\hline
\end{tabular}

\section{Limitations}

As previously stated, the demographic characteristics of the sample for this investigation were collected across four of the five participating institutions, with demographic data missing from the Mission Driven Private College. While the demographics of participants and characteristics of the sample share many commonalities with the overall demographics and composition of NCAA Division III, one limitation is that, across the four institutions where demographic data were collected, the percentage of athlete respondents who identified as men and women is not representative of the entire NCAA Division III athlete population. While this limitation may be mitigated by the fact that researchers have found male and female athletes to experience similar rates of hazing (Hamilton et al., 2013; McGlone, 2010; Waldron, 2015), it must be acknowledged. Additionally, given low response rates on some campuses, the length of time over which data were collected, and the fact that the institutions examined here account for $1.1 \%$ of the total institutional membership of NCAA Division III, data from this investigation may not be generalizable across the entire population of NCAA Division III athletes. Finally, these findings are reflective of a subset of NCAA Division III institutions that demonstrated a willingness to commit resources toward assessing the nature and extent of hazing on their campuses and therefore may not be representative of all NCAA Division III institutions.

\section{Discussion and Implications}

NCAA Division III institutions have not traditionally been the subject of scholarly inquiry, despite being the largest NCAA division in number of institutions and athletes ("Division III 2018-2019 facts and figures," 2018; Miranda, 2009). Previous researchers focused on athlete hazing in the United States have examined across NCAA divisions (e.g., Allan \& Madden, 2008; Van Raalte et al., 2007), with the notable exception of Hoover (1999) who concluded that athletes participating in NCAA Division III sports were equally as likely as their Division I and Division II peers to experience hazing. Given the membership growth, greater emphasis on competitiveness, and increase in institutional diversity NCAA Division III has experienced in the two decades since Hoover's findings, further examination of hazing in the context of 
NCAA Division III was warranted.

Our results are congruent with previous scholars who concluded: (a) athletes experience hazing at rates higher than their non-athlete peers (e.g., Allan \& Madden, 2008; Campo et al., 2005), (b) athletes are participating in high-risk and abusive hazing behaviors, (c) there is not a significant difference between the percentage of male and female athletes experiencing hazing (e.g., Hamilton et al., 2013; McGlone, 2010; Waldron, 2015), and (d) a gap exists between college athlete experiences of hazing and their ability to recognize and label those experiences as hazing (e.g., Hoover, 1999; Allan \& Madden, 2008). Despite this gap, when asked directly, varsity athletes were significantly more likely than their peers to indicate they were hazed even though they were less likely than peers to be aware of potential hazing on their teams prior to joining. This finding might suggest these athletes were more skilled or willing to identify hazing or they were less likely than their peers to minimize it or justify it as "just a tradition" or "team bonding", as documented in other investigations (Allan \& Madden, 2008). Interestingly though, the findings also revealed that Division III athletes in this investigation were significantly less likely than their peers to agree with attitude and perception questions that support non-hazing behavior (e.g., "hazing is not an effective way to create bonding") indicating athletes may be more tolerant of hazing. Taken together, these findings may indicate that having a foundational understanding about hazing, including the ability and willingness to label hazing behavior when it occurs, does not necessarily translate to possessing attitudes and beliefs that are thought to support non-hazing behavior and environments. Given this, more research is needed to understand the relationship between hazing knowledge (e.g., gained from a training or reading a policy) and attitudes and beliefs associated with hazing behavior. In addition to these findings that illuminate the nature and extent of hazing at the individual and group levels of the socio-ecological framework, findings from this research indicate there are factors at the institutional level as well and we turn to this discussion next.

The findings from this study suggest the potential for athlete hazing experiences and beliefs about hazing to significantly vary across NCAA Division III institutions, and perhaps along the lines of institutional-type as well. In contrast to NCAA Division I institutions where athletes tend to account for a smaller percentage of the student population, the overall institutional hazing climate-as conceptualized by scholars such as Cress (2002) and Hart and Fellabaum (2008) at NCAA Division III institutions may be amplified by the illustrated differences in athlete and non-athlete hazing experiences and beliefs about hazing. NCAA Division III athletes on average comprise $25 \%$ of the overall student body and may account for as much as $55 \%$ of the student population at some institutions ("Division III 2018-2019 facts and figures," 2018). Given this, it is likely varsity athletes can have a significant impact on 
the overall institutional hazing climate at NCAA Division III institutions. Scholars have noted the importance of targeting communities at-risk for interpersonal violence (e.g., Banyard, Moynihan, \& Plante, 2007) and suggested the visible position athletes occupy on campus may afford them the status to encourage non-athlete peers to engage in prevention efforts (e.g., Banyard, Moynihan, \& Crossman, 2009). Given this, we recommend practitioners prioritize this population with targeted prevention strategies that hold the potential to shift attitudes and change behaviors that are linked with hazing.

In the context of college athletics, hazing prevention is in nascent stages and literature evaluating prevention strategies is scarce (e.g., Capretto \& Keeler, 2012; Johnson \& Chin, 2016). Lessons learned from more established fields of prevention in college athletics and postsecondary contexts (e.g., sexual violence, binge drinking, and substance abuse) may be useful for Division III colleges and universities and provide a guide for hazing prevention. The campus ecology framework and established principles of prevention science (e.g., Dahlburg \& Krug, 2002; Nation et al., 2003) provide lenses for practitioners to translate promising strategies from other fields to prevent college athlete hazing. For example, like other interpersonal violence prevention on college campuses, our findings underscore the importance of examining individual, group, and community factors when developing strategies for hazing prevention (Bronfenbrenner, 1979; Dahl- burg \& Krug, 2002; Langford, 2004). Researchers have found media campaigns, bystander intervention trainings, and social norms messaging to be effective across individual, team, university community, and broader community levels for preventing interpersonal violence and substance misuse with college athletes (e.g., Doumas, Haustveit, \& Coll, 2010; Hummer, LaBrie, \& Lac, 2009; Moynihan, Banyard, Arnold, Eckstein, \& Stapleton, 2010).

While designing prevention efforts specific to college athletes is vital, a comprehensive approach seeks to promote institution-wide transformation so the factors that support and shape hazing behavior broadly are shifted to support campus safety instead. As such, strategies to effect change among athletes should ideally be integrated within broader efforts to address hazing as a campus-wide phenomenon. As well, rather than a "one size fits all" approach, findings from prevention science point to a comprehensive approach to hazing prevention that emphasizes the importance of assessment and provides for a targeted and tailored approach by considering different levels of the campus social ecology.

Findings shared from this research indicate these five NCAA Division III institutions, despite their interest in assessing and preventing hazing on their campuses, continued to have issues with hazing in the context of intercollegiate athletics, albeit at rates lower than previously observed. While researchers such as Hoover (1999) and Allan and Madden (2008) found that close to $80 \%$ of ath- 
letes experienced behaviors meeting the definition of hazing, the $40.9 \%$ of varsity athletes experiencing hazing in this study is congruent with several recent studies which have found between $50 \%$ and $58 \%$ of college athletes reporting hazing experiences (Johnson et al., 2018; Waldron, 2015), suggesting the need for further research to determine whether or not these results are limited to the context of institutions with concerted prevention efforts in place or if they represent larger shifts.

Providing an overview of NCAA Division III-focused research, Miranda (2009) noted that scholars examining athlete experiences in the division tended to be limited by inadequate sample sizes and unrepresentative groups. While not constrained by these limitations, given the previously outlined size and institutional diversity of Division III (Bass et al., 2014), assessing the nature and extent of athlete hazing at five colleges and universities is not sufficient to generalize results to the broader NCAA Division III population. Future research can seek to extend the preliminary findings shared here by broadening the number of institutions included in the data gathering pool, deepening analysis of hazing across institutional type within NCAA Division III, examining hazing across sports / sport type within the division, and gathering additional data on athlete perceptions of hazing experiences that can be used to inform social norms campaigns. Such research could lead to impactful hazing prevention strategies both with athletes and across the general student body.
In sum, while more research is warranted, this investigation helps fill gaps in the literature by exploring athlete hazing within NCAA Division III institutions specifically. Findings indicate that hazing continues to be a concern at these institutions, for both male and female athletes regardless of race, and that hazing may manifest differently depending on the type of DIII institution. While the findings may not be generalizable to all Division III institutions, the data suggest that, in order to support the health and safety of college students, hazing prevention is warranted at institutions with NCAA Division III athletes.

\section{Acknowledgements}

David Kerschner would like to acknowledge the support of the Janet Waldron Doctoral Research Fellowship at the University of Maine.

\section{References}

Allan, E. J., \& Madden, M. (2008). Hazing in view: College students at risk. http:// www.stophazing.org.

Allan, E. J., \& Madden, M. (2012). The nature and extent of college student hazing. International Journal of Adolescent Medicine and Health, 24(1), 83-90. https://doi.org/10.1515/ ijamh.2012.012

Allan, E. J., Kerschner, D., \& Payne, J. (2019). College student hazing experiences, attitudes, and perceptions: Implications for prevention. Journal of Student Affairs Research and Practice, 56(1), 32-48. https://doi.org/10.1080/19496591.2 018.1490303 
Anderson, E., McCormack, M., \& Lee, H. (2012). Male team sport hazing initiations in a culture of decreasing homohysteria. Journal of Adolescent Research, 27, 427-448. https://doi. org/10.1177/0743558411412957

Banyard, V., Moynihan, M., \& Plante, E. (2007). Sexual violence prevention through bystander education: An experimental evaluation. Journal of Community Psychology, 35, 463-481. https://doi.org/10.1002/jcop.20159

Banyard, V., Moynihan, M., \& Crossman, M. (2009). Reducing sexual violence on campus: The role of student leaders as empowered bystanders. Journal of College Student Development, 50, 446-457. https://doi. org/10.1353/csd.0.0083

Bass, J., Pfleegor, A., Katz, M., \& Schaeperkoetter, C. (2014, April). Why D3? A bolistic exploration of Division III institutions and their student-athletes. Paper presented at the College Sports Research Institute Conference, Columbia, SC.

Beaver, W. (2014). The changing nature of Division III athletics. College and University, 89(3), 34-40.

Borg, L. (2018, August 10). Salve Regina investigating allegations of hazing in football program. Providence Journal. https://www.providencejournal. com/news /20180810/salve-reginainvestigating-allegations-of-hazing-infootball-program

Brogan, B. (2013, April 4). Bowdoin College men's tennis team sanctioned for hazing, forfeits 4 matches. Bangor Daily News. https://bangordailynews. com/2013/ 04/04 /sports/reekcollege-mens-tennis-team sanctionedfor-hazing-forfeits-4-matches /

Bronfenbrenner, U. (1979). The Ecology of Human Development. Cambridge: Harvard University Press, pp. 1-348. https://doi. org/10.1080/00131728109336000 Bryshun, J., \& Young, K. (1999). Sportrelated hazing: An inquiry into male and female involvement. In P. White \& K. Young (Eds.), Sport and gender in Canada. Don Mills, Canada: Oxford University Press.

Campo, S., Poulos, G., \& Sipple, J. (2005). Prevalence and profiling: Hazing among college students and points of intervention. American Journal of Health Behavior, 29(2), 137-149. https://doi.org/10.5993/ajhb.29.2.5

Caperchione, C., \& Holman, M. (2004). Gender differences in coaches' perceptions of hazing in intercollegiate athletics. In J. Johnson \& M. Holman, (Eds.), Making the team: Inside the world of sport initiations and hazing (pp. 97117). Toronto, CA: Canadian Scholars' Press Inc.

Capretto, A., \& Keeler, L. (2012). Examination of a hazing workshop intervention for intercollegiate sport club athletes. Recreational Sports Journal, 36(2), 113-126. https://doi. org $/ 10.1123 / \mathrm{rsj} .36 .2 .113$

Cress, C. (2002). Campus climate. In A. M. Martinez \& K. A. Renn (Eds.), Women in bigher education: An encyclopedia (pp. 390-397). Santa Barbara, CA: ABC-CLIO, Inc.

Dahlburg, L., \& Krug, E. (2002). Violence: A global public health problem. 
In E. Krug, L. Dahlburg, J. Mercy, A. Zwi, \& R. Lozano (Eds.), World report on violence and health (pp. 1-56). Geneva, Switzerland: World Health Organization. https://doi.org/10.1136/ ip.9.1.93

Division III 2018-2019 facts and figures. (2018). https://ncaaorg.s3.amazonaws.com/ about/d3/201819D3_ FactandFigures.pdf.

Dorning, A. (2011, March 18).

Middlebury College suspends most of women's swim team over hazing. ABCNews. https://abcnews.go.com/ US/hazing-prompts-middleburycollege-cancel-womens-swim-team/ story?id $=13169051$

Doumas, D., Haustveit, T., \& Coll, K. (2010). Reducing heavy drinking among first year intercollegiate athletes: A randomized control trial of web-based normative feedback. Journal of Applied Sport Psychology, 22(3), 247-261. https:/ / doi. org/10.1080/10413201003666454

Dymski, G. (2012, September 14). SUNY Geneseo: Volleyball season canceled after hazing. Newsday. https://www. newsday.com/long-island/sunygeneseo- volleyball-season-canceledafter-hazing- 1.4003680

Gutowski, C., \& St. Clair, S. (2017a, September 19). 5 Wheaton College football players face felony charges in hazing incident. The Chicago Tribune. http://www.chicagotribune. $\mathrm{com} /$ news/local/breaking/ctwheaton-college-football-hazing-met20170918-story.html.
Gutowski, C., \& St. Clair, S. (2017b, September 23). Wheaton College at first stood by players accused of hazing, letter shows. The Chicago Tribune. http://www.chicagotribune. $\mathrm{com} /$ news/local/breaking/ctwheaton-college-hazing-charges-met20170922-story.html

Gutowski, C., \& St. Clair, S. (2018, March 16). Former Wheaton College football player sues school, former teammates over hazing incident. The Chicago Tribune. https://www. chicagotribune.com/news/local/ breaking/ct-met-wheaton-collegehazing-lawsuit-20180315-story.html. Hamilton, R., Scott, D., O’Sullivan, L. \& LaChapelle, D. (2013). An examination of the rookie hazing experiences of university athletes in Canada. Canadian Journal for Social Research, 3(1), 35-61. https://www. ciim.ca

Hart, J. \& Fellabaum, J. (2008). Analyzing campus climate studies: Seeking to define and understand. Journal of Diversity in Higher Education, 1(4), 222-234. https://doi.org/10.1037/ a0013627

Herz, N. (2008, January 25). Hazing investigation concludes? Mild hazing? The Bowdoin Orient. https:// bowdoinorient.com/bonus/ article/3211

Hoover, N. (1999). National survey: Initiation rites and athletics for NCAA sports teams. http://www.alfred.edu/ sports_hazing/docs/hazing.pdf. 
Hummer, J., LaBrie, J., \& Lac, A. (2009). The prognostic power of normative influences among NCAA student-athletes. Addictive Behaviors, 34(6), 573580. https://doi.org/10.1016/j. addbeh.2009.03.021.

Hutchinson, J. (2018, February 11). Opinion: Nudity, assault, theft and suspensions at Claremont-MuddScripps. The Panther. http://www. thepantheronline.com/sports/nudityassault-theft-suspensions-claremontmudd-scripps

Johnson, J., \& Chin, J. (2016). Hazing rites/rights: Using outdoor and adventure education-based orientation to effect positive change for first-year athletes. Journal of Adventure Education and Outdoor Learning, 16(1), 16-30. https://doi.org/10.1080/14729679.2 015.1050681 .

Johnson, J., Guerrero, M., Holman, M., Chin, J., \& Signer-Kroeker, M. (2018). An examination of hazing in Canadian intercollegiate sports. Journal of Clinical Sport Psychology, 12(2), 144-159. https://doi.org/10.1123/ jcsp.2016-0040

Katz, M., Pfleegor, A., Schaeperkoetter, C., Bass, J. (2015). Factors for success in NCAA Division III athletics. Journal of Issues in Intercollegiate Athletics, 8, 102-122. http://csri-jiia.org/

Keith, B. (2019, November 27). NCAA Division III Ursinus College cancels remainder of 2019-20 swimming season. SwimSwam. https:/ / swimswam.com/ncaa-division-iiiursinus-college-cancels-remainder-of2019-20-swimming-season/
Koop, C. (2017, September 24). At first Wheaton College game since hazing charges, fans support players. The Daily Herald. https://www.dailyherald. com/news/20170923/at-firstwheaton-college-game-since-hazingcharges-fans-support-players.

Kowalski, C., \& Waldron, J. (2010). Looking the other way: Athletes' perceptions of coaches' responses to hazing. International Journal of Sports Science \& Coaching, 5(1), 87-100. https://doi. org/10.1260/1747-9541.5.1.87

Lafferty, M., Wakefield, C., \& Brown, H. (2016). "We do it for the team": Student- athletes' initiation practices and their impact on group cohesion. International Journal of Sport and Exercise Psychology, 15(4), 438-446. https://doi.org/10.1080/161219 $7 \times 2015.1121507$

Langford, L. (2004). Preventing violence and promoting safety in higher education settings: Overview of a comprehensive approach. Washington, DC: The Higher Education Center for Alcohol and Other Drug Abuse and Violence Prevention.

Lederman, D. (2008, April 11). Division IV is dead. Inside Higher Ed. https://www.insidehighered.com/ news/2008/04/11/divisioniii

Markham, C. (2016, September 16). UMW swim team caught for hazing, forfeit first meet. The Blue \& Gray Press. https://blueandgraypress. com/2016/09/16/umw-swim-teambusted-for-hazing-forfeit-first-meet/ Mayer, G. (2006, February 16). Violations of team policy halt men's season 
Panthers blocked from postseason competition because of hazing offenses. The Middlebury Campus. https://middleburycampus. com/4798/sports/violationsof- team-policy-halt-mens-seasonpanthers-blocked-from-postseasoncompetition-because-of-hazingoffenses/

McGlone, C. (2010). Hazy viewpoints: Administrators' perceptions of hazing. International Journal of Sport Management and Marketing, 7, 119131. https://doi.org/10.1504/ ijsmm.2010.029716

Miranda, M. (2009). Anecdote or data: Research on NCAA Division III academic performance and the Division III presidential white papers. Journal of Intercollegiate Sport, 1, 9-15. https://doi.org/10.1123/jis.2.1.9

Moynihan, M., Banyard, V., Arnold, J., Eckstein, R., \& Stapleton, J. (2010). Engaging intercollegiate athletes in preventing and intervening in sexual and intimate partner violence. Journal of American College Health, 59(3), 197204. https://doi.org/10.1080/074484 81.2010 .502195

Nation, M., Crusto, C., Wandersman, A., Kumpfer, K., Seybolt, D., MorrisseyKane, E., \& Davino, K. (2003). What works in prevention: Principles of effective prevention programs. American Psychologist, 58(6), 449-456. https://doi.org/10.1037/0003066x58.6-7.449

National Collegiate Athletic Association. (2018). Sport sponsorship, participation, and demographics search [data file].
http://web1.ncaa.org/rgdSearch/ exec/main.

NCAA. (2019). NCAA Division III. Retrieved from http://www.ncaa.org/ d3.

Nuwer, H. (Ed.). (2018). Hazing: Destroying young lives. Bloomington, IN: Indiana University Press.

Powers, E. (2008, January 15).

Growing pains. Inside Higher Ed. https://www.insidehighered.com/ news $/ 2008 / 01 / 15 /$ ncaa

Renn, K.A. \& Patton, L. D. (2011). Campus ecology and environments. In Schuh, J. H., Jones, Susan, R., Harper, S. R. \& Associates (Eds.), Student services: $A$ bandbook for the profession, (pp. 242-256). San Francisco: Jossey-Bass.

Schwartzburg, A. (2010, September 27). In defense of sports teams' shenanigans. The College Voice. https:// thecollegevoice.org/2010/09/27/ teamshenanigans/

Snowdon, H., \& Rod, M. (2018, February 18). CMS track teams suspended indefinitely after naked athletes allegedly assault Pomona student. The Student Life. https:/ / tsl.news/ news7224/

Srabstein, J. (2008). Deaths linked to bullying and hazing. International Journal of Adolescent Medicine and Health, 20(2), 235-239. https://doi. org/10/1515/ijamh.2008.20.2.235

Srabstein, J., Joshi, P., Due, P., Wright, J., Leventhal, B., Merrick, J.,... Riibner, K. (2008). Prevention of public health risks linked to bullying: A need for a whole community 
approach. International Journal of Adolescent Medicine and Health, 20(2), 185-199. https://doi.org/10/1515/ ijamh.2008.20.2.185

Stack, L., \& Hauser, C. (2017, September 19). Wheaton College football players charged with violent hazing attach. The New York Times. https://www. nytimes.com/2017/09/19/us/ wheaton-college-hazing.html Van Raalte, J., Cornelius, A., Linder, D. \& Brewer, B. (2007). The relationship between hazing and team cohesion. Journal of Sports Behavior, 30, 491-507.

Waldron, J., \& Kowalski, C. (2009). Crossing the line. Research Quarterly for Exercise and Sport, 80(2), 291-302. https://doi.org/10.1080/02701367.2 009.10599564

Waldron, J. (2015). Predictors of mild hazing, severe hazing, and positive initiation rituals in sport. Journal of Sports Science \& Coaching, 10(6), 10891101. https://doi.org/10.1260/17479541.10.6.1089
Waldron, J. (2016). Hazing in sport. In R.J. Schinke, K.R. McGannon, \& B. Smith (Eds.), Routledge international handbook of sport psychology (pp. 304312). Routledge.

Ward, C. (2018, September 18). Settlement reached in lawsuit filed over Wheaton College football hazing incident. The Chicago Tribune. https://www.chicagotribune.com/ suburbs/ct-met-wheaton-collegehazing-civil-suit-settlement-20180918story.html

Ward, C. (2019, March 22). 'Least culpable' of ex-Wheaton College football players charged in hazing incident pleads guilty to misdemeanor. The Chicago Tribune. https://www.chicagotribune.com/ suburbs/ct-met-wheaton-collegefootball-hazing-plea-20190322-story. html

Wheaton College (2017, September 20). Statement on charges in hazing incident. https://www.wheaton. edu/news/statements/statement-oncharges-in-hazing-incident/. 